\title{
Sulfate Reduction and Sulfur Cycles at Two Seagrass Beds Inhabited by Cold Affinity Zostera marina and Warm Affinity Halophila nipponica in Temperate Coastal Waters
}

\author{
Bomina Kim ${ }^{1}$ - Ayeon Choi ${ }^{1}$ - Kun-Seop Lee ${ }^{2}$ C Chang-Keun Kang ${ }^{3}$. Jung-Ho Hyun ${ }^{1}$
}

Received: 18 July 2016 /Revised: 3 February 2017 / Accepted: 7 February 2017 / Published online: 13 March 2017

(C) The Author(s) 2017. This article is published with open access at Springerlink.com

\begin{abstract}
To evaluate the impact of invading seagrass on biogeochemical processes associated with sulfur cycles, we investigated the geochemical properties and sulfate reduction rates (SRRs) in sediments inhabited by invasive warm affinity Halophila nipponica and indigenous cold affinity Zostera marina. A more positive relationship between SRR and belowground biomass (BGB) was observed at the H. nipponica bed $\left(\mathrm{SRR}=0.6809 \times \mathrm{BGB}-4.3162, r^{2}=0.9878, p=0.0006\right)$ than at the $Z$. marina bed $\left(\mathrm{SRR}=0.3470 \times \mathrm{BGB}-4.0341, r^{2}=0.7082\right.$, $p=0.0357)$. These results suggested that SR was more stimulated by the dissolved organic carbon (DOC) exuded from the roots of $H$. nipponica than by the DOC released from the roots of $Z$. marina. Despite the enhanced SR in spring-summer, the relatively lower proportion (average, 20\%) of acid-volatile sulfur (AVS) in total reduced sulfur and the strong correlation between total oxalate-extractable $\mathrm{Fe}\left(\mathrm{Fe}_{(\text {oxal })}\right)$ and chromium-reducible sulfur $\left(\mathrm{CRS}=0.2321 \times\right.$ total $\mathrm{Fe}_{(\text {oxal })}+1.8180, r^{2}=0.3344$, $p=0.0076)$ in the sediments suggested the rapid re-oxidation of sulfide and precipitation of sulfide with $\mathrm{Fe}$. The turnover rate of the AVS at the H. nipponica bed $\left(0.13\right.$ day $\left.^{-1}\right)$ was 2.5 times lower than that at the $Z$. marina bed $\left(0.33 \mathrm{day}^{-1}\right)$. Together with lower AVS turnover, the stronger correlation of SRR to BGB in
\end{abstract}

Communicated by Bongkeun Song

Jung-Ho Hyun

hyunjh@hanyang.ac.kr

1 Department of Marine Sciences and Convergent Technology, Hanyang University, Ansan, Gyeonggi-do 15588, South Korea

2 Department of Biological Sciences, Pusan National University, Pusan 46241, South Korea

3 Schoole of General Studies, GIST College, Gwangju Institute of Science and Technology, Gwangju 61005, South Korea the H. nipponica bed suggests that the extension of H. nipponica resulting from the warming of seawater might provoke more sulfide accumulation in coastal sediments.

Keywords Climate change $\cdot$ Zostera marina $\cdot$ Halophila nipponica $\cdot$ Sulfate reduction $\cdot \mathrm{S}$ cycles

\section{Introduction}

Seagrass is the most productive marine flowering plant (Hemminga and Duarte 2000) and is regarded as an ecosystem engineer due to its physical, chemical, and biological influences on coastal environments (Orth et al. 2006; Waycott et al. 2009; Connolly 2012; Fourqurean et al. 2012; Kaldy 2012). Seagrasses incorporate substantial amounts of carbon dioxide into the organic carbon pool of their tissues and transfer it to rhizospheres, where the organic carbon is rapidly recycled (Short et al. 2007; Nellemann et al. 2009). Accordingly, relatively higher benthic mineralization occurs at seagrass beds compared with unvegetated sediments (Marbà et al. 2006). Because the inorganic $\mathrm{N}$ and $\mathrm{P}$ produced via benthic mineralization in the seagrass bed are a major nutrient source for plant growth (Shorts 1987), organic carbon $\left(\mathrm{C}_{\mathrm{org}}\right)$ oxidation in seagrass bed plays an important role in carbon and nutrient cycling in coastal environments (Holmer et al. 2001; Devereux 2005).

$\mathrm{C}_{\text {org }}$ mineralization in the sediment is processed by a variety of microbes using various electron acceptors, such as oxygen, nitrate, manganese oxide, iron oxide, and sulfate (Canfield et al. 2005). Due to the high sulfate concentration $(28 \mathrm{mM})$ in seawater, sulfate reduction is considered to be among the most important anaerobic $\mathrm{C}_{\text {org }}$ mineralization pathways in marine sediments (Blackburn et al. 1994; Holmer and Nielsen 1997; Holmer et al. 2001; Hyun et al. 2007, 2009). 
Major environmental and ecological issues resulting from enhanced sulfate reduction in seagrass beds include the accumulation of phytotoxic dissolved sulfide (Marbà and Duarte 2010; Gracía et al. 2012, 2013) and the release of inorganic nutrients into the sediment (Holmer et al. 2001; Marbà et al. 2006). The accumulation of sulfide might deteriorate the growth of seagrass, which consequentially incurs seagrass mortality (Terrados et al. 1999; Borum et al. 2005). In addition, because sulfide is highly reactive and quickly re-oxidized by oxygen, nitrate, and iron oxides, the accumulation of sulfide further stimulates the anoxic condition of the sediment (Canfield et al. 2005), which largely regulates the behavior of nutrients and metals (Jørgensen 1977; Azzoni et al. 2001). Therefore, biogeochemical studies on the $\mathrm{S}$ cycles together with the quantification of sulfate reduction and its regulation are particularly important to evaluate and predict the variations of coastal ecosystems where seagrass plays an important role as a major primary producer.

Global climate change has increased the sea surface temperature (SST) to approximately $0.64{ }^{\circ} \mathrm{C}$ over the last 50 years (IPCC 2007; Nellemann et al. 2009). An increase in SST ultimately induces thermal stress on indigenous seagrasses inhabiting temperate coastal areas, thereby decreasing seagrass diversity (Diaz-Amela et al. 2007; Marbà and Duarte 2010; Rasheed and Unsworth 2011; Pergent et al. 2014; Zimmerman et al. 2015). Several studies have also shown that a decline in the native seagrass population is associated with the increased sulfate reduction rates and sulfide accumulation resulting from increased water temperature in the seagrass bed (Koch et al. 2007; Gracía et al. 2012, 2013). In contrast to the deleterious thermal effects on indigenous seagrasses, global warming might provide an opportunity for tropical and subtropical invasive species to expand into new habitats in the temperate zone (Koch et al. 2007). For example, species in the genus Halophila, which predominantly occur in tropical/subtropical regions (den Hartog and Kuo 2006; Kuo et al. 2006a, 2006b; Short et al. 2007), have expanded their distribution range into various sediments in temperate zones dominated by Zostera marina (Kuo et al. 2006a, 2006b; Short et al. 2006; Kim et al. 2009). Because of its potential impact on element cycles, food web processes and ecosystem function, ecological and environmental concerns regarding these invasive species have increased (Holmer et al. 2009; ISAC 2011).

The annual mean SST in southern coastal waters in the Korean peninsula increased from 15.4 to $16.4{ }^{\circ} \mathrm{C}$ between 1933 and 2006 (Kim et al. 2009). As a result of the warmer SST, Halophila nipponica, which is generally distributed in warm temperate Japanese water (Kuo et al. 2006b), has been observed in areas (Kim et al. 2009; Kim et al. 2012) where cold affinity $Z$. marina is typically the dominant native seagrass species (Lee and Lee 2003; Lee et al. 2005). Despite the obvious interaction between plants and microbial processes (Marbà and Duarte 2010; Gracía et al. 2012, 2013), little is known about the effects of indigenous and invading seagrass species on the biogeochemical processes in Korean coastal sediments. The main objective of the present study was to elucidate the biogeochemical process in sediments inhabited by $Z$. marina and $H$. nipponica, with special emphasis on the $\mathrm{S}$ cycles associated with sulfate reduction. To our knowledge, this study is the first to report the potential biogeochemical impact of a warm affinity invasive seagrass, $H$. nipponica, related to climate change in temperate coastal sediments.

\section{Materials and Methods}

\section{Study Area}

The study area was located on the southern coast of Korea $\left(34^{\circ} 43^{\prime} 41.99^{\prime \prime} \mathrm{N}, 128^{\circ} 02^{\prime} 07.53^{\prime \prime} \mathrm{E}\right.$; Fig. 1) where two seagrass species (Z. marina and H. nipponica) occupied different spaces at a close distance. The sampling was conducted six times, in July, August, and November in 2012; in June and August in 2013; and in February 2014. The average water depth was approximately $4-5 \mathrm{~m}$ below the mean low water, and the sediment was characterized as slightly gravelly sand or sand (from 93 to $97 \%$ sand).

\section{Seagrass Parameters}

To measure the shoot density and above- and below-ground biomass, a scuba diver collected the samples. All above- and below-ground tissues within a haphazardly thrown quadrat $(0.2 \times 0.2 \mathrm{~m} ; n=4)$ were collected to measure shoot density and biomass. Seagrass shoots were counted to estimate the shoot density per unit area. The collected plant samples were rinsed in freshwater to remove epiphytes and sediment, separated into above- and below-ground tissues, and dried to a constant weight at $60{ }^{\circ} \mathrm{C}$. The samples were subsequently weighed and converted to per unit area estimates (g dry weight $\mathrm{m}^{-2}$ ).

\section{Sediment Sampling and Handling}

A scuba diver collected sediment samples in triplicate using polycarbonate cores $(6 \mathrm{~cm}$ i.d.). The cores were brought to the surface water using core racks to keep the sediments undisturbed. The surface sediment temperature was measured immediately onboard using a thermometer. The cores were immediately sealed with butyl rubber stoppers and placed in a cooler (at about $4{ }^{\circ} \mathrm{C}$ ) until further processing in the laboratory. Pore-water was extracted using Rhizon soil moisture samplers (Rhizosphere Research Products, Wageningen, The Netherlands). Pore-water for measuring dissolved 


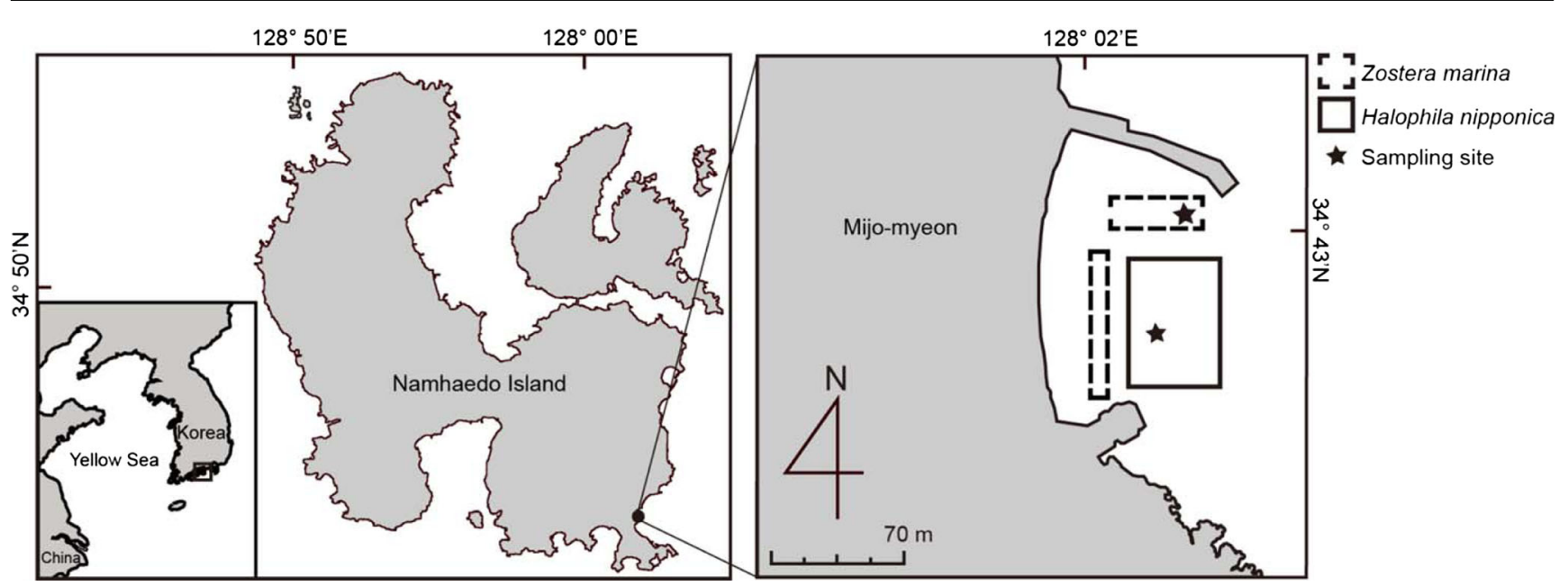

Fig. 1 Sampling sites inhabited by two seagrasses, Zostera marina (ZM) and Halophila nipponica (HN), in the southern coast of Korea

inorganic carbon (DIC) was preserved with saturated $\mathrm{HgCl}_{2}$ solution, and inorganic nutrients were stored in $\mathrm{HCl}$ solution $(0.1 \mathrm{~N})$. The sulfate and dissolved iron $\left(\mathrm{Fe}^{2+}\right)$ in pore-water were mixed with $\mathrm{HCl}(0.1 \mathrm{~N})$. Dissolved sulfide was precipitated with $\mathrm{Zn}$ acetate solution (20\%) and subsequently stored at $-20^{\circ} \mathrm{C}$. In a $\mathrm{N}_{2}$ gas-filled glove bag, the sediment cores for measuring the solid phase constituent were sliced at $3-\mathrm{cm}$ intervals down to a 9-cm depth and immediately frozen. The sediment cores for measuring porosity were sliced and analyzed in the laboratory. The sediment samples used to measure organic matter content and chlorophyll-a (Chl-a) were sliced and subsequently stored at $-20{ }^{\circ} \mathrm{C}$ until further analysis.

\section{Laboratory Analysis}

Dissolved inorganic carbon and ammonium $\left(\mathrm{NH}_{4}{ }^{+}\right)$were analyzed by flow injection analysis with conductivity detection (Amber Science Inc., Eugene, OR, USA; Hall and Aller 1992). Inorganic phosphate $\left(\mathrm{PO}_{4}{ }^{3-}\right)$ was measured using a nutrient autoanalyzer (Proxima, Alliance Inc.; Grasshoff et al. 1999). The sulfate concentration $\left(\mathrm{SO}_{4}{ }^{2-}\right)$ in the porewater was measured using ion chromatography (Metrohm 761; Metrohm, Herisau, Switzerland). Dissolved sulfide $\left(\mathrm{H}_{2} \mathrm{~S}\right)$ was determined according to the methylene blue method (Cline 1969). Dissolved iron $\left(\mathrm{Fe}^{2+}\right)$ was determined by colorimetry with ferrozine solution (Stookey 1970). The sediment density was calculated according to the weight of a known volume, and the water content was obtained after drying at $60{ }^{\circ} \mathrm{C}$ for $48 \mathrm{~h}$. Porosity was determined from the sediment density and water content. The organic matter content (loss of ignition, or LOI) was estimated before and after drying at $60^{\circ} \mathrm{C}$ for $48 \mathrm{~h}$, and subsequently, the sample was ground in a ball mill and combusted at $450{ }^{\circ} \mathrm{C}$ for $4 \mathrm{~h}$ (Lavery et al. 2013). Grain size was determined only once (in July 2012). Sediment samples for particle size analysis were separated from sand particles through a 40-mesh sieve, and fine particles were counted using an automatic particle size analyzer (Mastersizer 2000, Malvern, UK). Textural parameters were determined using graphical methods (Folk and Ward 1957). The Chl-a concentration was determined using a spectrophotometer after extraction with $90 \%$ acetone at $4{ }^{\circ} \mathrm{C}$ for $24 \mathrm{~h}$ in the dark (Parsons et al. 1984).

Total oxalate-extractable $\mathrm{Fe}(\mathrm{Fe}[\mathrm{II}]+\mathrm{Fe}[\mathrm{III}])$ was extracted using $0.2 \mathrm{M}$ oxic oxalate solution ( $\mathrm{pH} 3$ ) for $4 \mathrm{~h}$ from air-dried sediment and determined using ferrozine (ferrozine reagent with $1 \%$ hydroxylamine hydrochloride); the absorbance was read after $4 \mathrm{~h}$ (Canfield et al. 1993; Thamdrup and Canfield 1996). $\mathrm{Fe}(\mathrm{II})$ was extracted from the frozen sediment in anoxic oxalate (Phillips and Lovley 1987). The total oxalateextractable $\mathrm{Fe}$ and $\mathrm{Fe}(\mathrm{II})$, hereafter total $\mathrm{Fe}_{(\text {oxal }}$ and $\mathrm{Fe}(\mathrm{II})_{(\text {oxal) }}$, respectively, were determined by ferrozine solution. Oxalate-extractable Fe(III), hereafter Fe(III) $)_{\text {(oxal), was de- }}$ fined as the difference between total $\mathrm{Fe}_{(\text {oxal) }}$ and $\mathrm{Fe}$ (II) (oxal) . This fraction represents poorly crystalline Fe(III) oxides. To determine the total reduced sulfur (TRS) in the sediment, including acid-volatile sulfur $\left(\mathrm{AVS}=\mathrm{FeS}+\mathrm{H}_{2} \mathrm{~S}\right)$ and chromium-reducible sulfur $\left(\mathrm{CRS}=\mathrm{S}^{0}+\mathrm{FeS}_{2}\right)$, the sediment samples were fixed with $\mathrm{Zn}$ acetate solution (20\%) and frozen. TRS was recovered using two-step distillation with cold $12 \mathrm{M}$ $\mathrm{HCl}$ and boiling with $0.5 \mathrm{M} \mathrm{Cr}^{2+}$ solution (Fossing and Jørgensen 1989), and, subsequently, sulfide was determined according to the method of Cline (1969).

\section{Rates of Sulfate Reduction and AVS Turnover}

Sulfate reduction rates (SRRs) were determined using the radiotracer method of Jørgensen (1978). Triplicate intact cores $(20 \mathrm{~cm}$ long with $2 \mathrm{~cm}$ i.d.) were collected from each site. Two microcuries of ${ }^{35} \mathrm{SO}_{4}{ }^{2-}$ (iZotope Co., Ltd.) was injected into injection ports at $1-\mathrm{cm}$ intervals, and the cores were incubated for $2 \mathrm{~h}$ at an 
in situ temperature. At the end of the incubation, the sediment was sliced into sections, fixed in $\mathrm{Zn}$ acetate (20\%), and frozen until processed in the laboratory (Fossing and Jørgensen 1989). The reduced $\mathrm{S}$ was recovered using the two-step distillation method of Fossing and Jørgensen (1989), and the radioactivity of the reduced ${ }^{35} \mathrm{~S}$ was quantified using a liquid scintillation counter (Tri-Carb 2910TR; PerkinElmer, Waltham, MA, USA). The turnover rates of AVS produced by sulfate reduction were calculated by dividing the SRR by AVS.

\section{Statistics}

Student's $t$ tests were used to compare the difference of means for geochemical parameters between the two seagrass beds. One-way analysis of variance (ANOVA) was used to evaluate seasonal variations in biogeochemical parameters in each seagrass bed. Prior to analysis, the homogeneity of variance was checked using Levene's test. Turkey's post hoc analysis was used to compare means when significant differences were detected by ANOVA. Pearson's correlation analysis was used to evaluate the relationships between sulfate reduction, sediment temperature, and seagrass biomass. Probabilities $(p)$ of $<0.05$ were considered significant.

\section{Results}

\section{Environmental Parameters}

The sediment temperature ranged from 7 to $25^{\circ} \mathrm{C}$ during the study period (Table 1). Porosity ranged from 0.4 to 0.5 , and the LOI in the sediments ranged from 0.6 to $1.2 \%$ of the dry sediment (Table 1). The sediment consisted of a relatively fine grain size, slightly gravelly sand to sand. The Chl-a concentrations in the surface sediments ranged from 108 to $172 \mathrm{mg} \mathrm{m}^{-2}$ and from 215 to $266 \mathrm{mg} \mathrm{m}^{-2}$ in spring-summer (June, July, and August) and winter (November and February), respectively (Table 1).

\section{Seagrass Density and Biomass}

The shoot density ranged from 268 to 533 shoots $\mathrm{m}^{-2}$ for $Z$. marina with an average $( \pm 1$ SD) of $382 \pm 102$ shoots $\mathrm{m}^{-2}$ and from 1525 to 4092 shoots $\mathrm{m}^{-2}$ for H. nipponica $\left(3276 \pm 1046\right.$ shoots $\left.\mathrm{m}^{-2}\right)$ and exhibited clear seasonal variation at both seagrass beds (Table 1). The shoot density of $Z$. marina was highest in June 2013 and lowest in November 2012, while the density of $H$. nipponica was highest in August 2012 and lowest in February 2014. The above- and belowground biomass showed significant seasonal variations at both seagrass beds $(p<0.05$, Table 1$)$. The above- ground biomass (AGB) was highest in June 2013 (420 $\mathrm{g} \mathrm{DW} \mathrm{m}^{-2}$ ) and lowest in November 2012 (34 g $\mathrm{DW} \mathrm{m}^{-2}$ ) at the $Z$. marina bed and highest in August 2013 (21 $\mathrm{g} \mathrm{DW} \mathrm{m}^{-2}$ ) and lowest in February 2014 (4 g $\mathrm{DW} \mathrm{m}^{-2}$ ) at the $H$. nipponica bed. The below-ground biomass (BGB) was highest in July 2012 (97 g DW $\mathrm{m}^{-2}$ ) and lowest in November 2012 (22 g $\mathrm{DW} \mathrm{m}^{-2}$ ) at the $Z$. marina bed and highest in August 2012 (29 $\mathrm{g} \mathrm{DW} \mathrm{m}^{-2}$ ) and lowest in June 2013 (9 g $\mathrm{DW} \mathrm{m}^{-2}$ ) at the $H$. nipponica bed. The BGB to AGB ratio of $Z$. marina was highest in November $2012(0.66)$ and lowest in June 2013 (0.17) (Table 1). The ratio of $H$. nipponica was highest in February 2014 (2.55) and lowest in November 2012 (0.86) (Table 1). The ratio of $H$. nipponica was approximately three times higher (average, 1.50) than that of $Z$. marina (average, 0.42).

\section{Geochemical Properties}

The depth-integrated $(0-6 \mathrm{~cm})$ concentrations of DIC, $\mathrm{NH}_{4}{ }^{+}, \mathrm{PO}_{4}{ }^{3-}, \mathrm{SO}_{4}{ }^{2-}, \mathrm{H}_{2} \mathrm{~S}$, and $\mathrm{Fe}^{2+}$ were not significantly different between the two seagrass beds ( $p=0.519,0.170,0.854,0.951,0.685$, and 0.717 , respectively), but the concentrations significantly varied with season (Table 2). The depth-integrated $(0-6 \mathrm{~cm})$ concentrations of DIC, $\mathrm{SO}_{4}{ }^{2-}$, and $\mathrm{H}_{2} \mathrm{~S}$ were higher in August 2013 and lower in July 2012. $\mathrm{PO}_{4}{ }^{3-}$ concentrations were highest in June-August 2013 and lower in August 2012. $\mathrm{NH}_{4}{ }^{+}$concentrations were higher in August 2012 and lower in July 2012 at the Z. marina bed, while these concentrations were higher in August 2013 and lower in February 2014 at the H. nipponica bed. $\mathrm{Fe}^{2+}$ concentrations were higher in July and August at both seagrass beds, but the average dissolved $\mathrm{Fe}^{2+}$ concentrations were generally low $(<10 \mu \mathrm{M}$, data not shown). Sulfide concentrations were below the detection limit ( $<3 \mu \mathrm{M}$, data not shown).

The $\mathrm{Fe}(\mathrm{II})_{(\mathrm{oxal})}$ content in the sediments ranged from 0 to $2.6 \mu \mathrm{mol} \mathrm{cm} \mathrm{cm}^{-3}$, and $\mathrm{Fe}(\mathrm{III})_{(\mathrm{oxal})}$ ranged from 20.0 to $48.6 \mu \mathrm{mol} \mathrm{cm}{ }^{-3}$ (data not shown). The depth-integrated (0$6 \mathrm{~cm})$ concentrations of total $\mathrm{Fe}_{(\text {oxal }}\left(\mathrm{Fe}[\mathrm{II}]_{(\text {oxal })}+\mathrm{Fe}[\mathrm{III}]_{(\text {oxal })}\right)$ showed significant seasonal variation (one-way ANOVA, $Z$. marina bed: $F_{3,8}=7.056, p=0.012 ; H$. nipponica bed: $F_{2,6}=40.534, p=0.000$ ) and were not significantly different between the two seagrass beds $(p=0.711)$ (Fig. 2a, b). Total $\mathrm{Fe}_{\text {(oxal) }}$ was highest in June 2013 and August 2012 (2906 $\mathrm{mmol} \mathrm{m}^{-2}$ at the Z. marina bed and $2629 \mathrm{mmol} \mathrm{m}^{-2}$ at the $H$. nipponica bed) and lowest in July 2012 (1509 $\mathrm{mmol} \mathrm{m}^{-2}$ at the Z. marina bed and $1323 \mathrm{mmol} \mathrm{m}^{-2}$ at the $H$. nipponica bed). However, the iron pools were dominated by $\mathrm{Fe}(\mathrm{III})_{\text {(oxal) }}$ during all seasons, comprising 94-100\% of the total $\mathrm{Fe}_{\text {(oxal) }}$ (Fig. 2a, b). The pools of total reduced sulfur $($ TRS $=$ AVS + CRS) varied with season at both 
Table 1 Environmental parameters of sediments inhabited by Z. marina $(\mathrm{ZM})$ and H. nipponica $(\mathrm{HN})$ and biological characteristics of two seagrass species

\begin{tabular}{|c|c|c|c|c|c|c|c|}
\hline \multirow[t]{2}{*}{ Parameter } & \multirow[t]{2}{*}{ Site } & \multicolumn{3}{|l|}{2012} & \multicolumn{2}{|l|}{2013} & \multirow{2}{*}{$\begin{array}{l}2014 \\
\text { February }\end{array}$} \\
\hline & & July & August & November & June & August & \\
\hline Temperature $\left({ }^{\circ} \mathrm{C}\right)$ & $\begin{array}{l}\mathrm{ZM} \\
\mathrm{HN}\end{array}$ & 21.8 & 25.0 & 11.5 & 21.0 & 23.0 & 7.0 \\
\hline \multirow[t]{2}{*}{ Porosity } & $\mathrm{ZM}$ & 0.4 & 0.4 & 0.4 & 0.5 & 0.5 & 0.4 \\
\hline & $\mathrm{HN}$ & 0.4 & 0.4 & 0.4 & - & 0.5 & 0.4 \\
\hline \multirow[t]{2}{*}{ OM (\% dry wt.) } & $\mathrm{ZM}$ & 0.7 & - & 0.8 & 0.6 & 1.1 & 1.0 \\
\hline & $\mathrm{HN}$ & 1.1 & - & 1.0 & - & 0.9 & 1.2 \\
\hline \multirow[t]{2}{*}{ Chl-a $\left(\mathrm{mg} \mathrm{m}^{-2}\right)$} & $\mathrm{ZM}$ & 108 & 157 & 215 & 122 & 172 & 245 \\
\hline & $\mathrm{HN}$ & 153 & 140 & 239 & - & 165 & 266 \\
\hline \multirow[t]{2}{*}{ Shoot density $\left(\mathrm{m}^{-2}\right)$} & $\mathrm{ZM}$ & 473 & 306 & 268 & 533 & 375 & 337 \\
\hline & $\mathrm{HN}$ & 4049 & 4092 & 3495 & 2609 & 3219 & 1525 \\
\hline \multicolumn{8}{|l|}{ Biomass (g DW m ${ }^{-2}$ ) } \\
\hline \multirow[t]{2}{*}{ Above-ground (AGB) } & $\mathrm{ZM}$ & 180 & 99 & 34 & 420 & 220 & 147 \\
\hline & $\mathrm{HN}$ & 12 & 19 & 14 & 6 & 21 & 4 \\
\hline \multirow[t]{2}{*}{ Below-ground (BGB) } & $\mathrm{ZM}$ & 97 & 58 & 22 & 69 & 74 & 33 \\
\hline & $\mathrm{HN}$ & 18 & 29 & 12 & 9 & 23 & 10 \\
\hline \multirow[t]{2}{*}{$\mathrm{BGB} / \mathrm{AGB}$ ratio } & $\mathrm{ZM}$ & 0.54 & 0.59 & 0.66 & 0.17 & 0.34 & 0.22 \\
\hline & $\mathrm{HN}$ & 1.48 & 1.52 & 0.86 & 1.50 & 1.09 & 2.55 \\
\hline
\end{tabular}

seagrass beds (one-way ANOVA, Z. marina bed: $F_{5,12}=6.353, p=0.004 ; H$. nipponica bed: $F_{4,10}=3.458$, $p=0.051$ ) (Fig. 2c, d). The TRS was highest in November $2012\left(888 \mathrm{mmol} \mathrm{m}^{-2}\right)$ and lowest in August 2012 $\left(520 \mathrm{mmol} \mathrm{m}^{-2}\right)$ at the $Z$. marina bed and highest in November $2012\left(569 \mathrm{mmol} \mathrm{m}^{-2}\right)$ and lowest in July 2012 $\left(280 \mathrm{mmol} \mathrm{m}^{-2}\right.$ ) at the $H$. nipponica bed. The TRS was generally higher at the $Z$. marina bed $\left(631 \pm 140 \mathrm{mmol} \mathrm{m}^{-2}\right)$ than at the H. nipponica bed $\left(433 \pm 121 \mathrm{mmol} \mathrm{m}^{-2}\right)$. The sulfur pools were generally dominated by the CRS fraction (63$90 \%)$

\section{SRRs and AVS Turnover}

SRRs significantly varied with season at the two seagrass beds (one-way ANOVA, $Z$. marina bed: $F_{5,12}=24.444, p=0$; $H$. nipponica bed: $F_{4,10}=25.534, p=0$; Fig. 3 ). The maximum SRR at the Z. marina bed was observed in June 2013
Table 2 Depth-integrated $(0-6 \mathrm{~cm})$ inventories of the pore-water constituents in the sediments inhabited by $Z$. marina (ZM) and H. nipponica (HN)

\begin{tabular}{|c|c|c|c|c|c|c|c|}
\hline \multirow[t]{2}{*}{ Parameter } & \multirow[t]{2}{*}{ Site } & \multicolumn{3}{|c|}{2012} & \multicolumn{2}{|l|}{2013} & \multirow{2}{*}{$\begin{array}{l}2014 \\
\text { February }\end{array}$} \\
\hline & & July & August & November & June & August & \\
\hline \multicolumn{8}{|c|}{ Pore-water $\left(\mathrm{mmol} \mathrm{m}^{-2}\right)$} \\
\hline \multirow[t]{2}{*}{ DIC } & $\mathrm{ZM}$ & 50 & 71 & 61 & 69 & 73 & 55 \\
\hline & $\mathrm{HN}$ & 45 & 65 & 56 & - & 78 & 49 \\
\hline \multirow[t]{2}{*}{$\mathrm{NH}_{4}^{+}$} & $\mathrm{ZM}$ & 1.40 & 1.60 & 1.10 & 1.30 & 1.27 & 1.05 \\
\hline & $\mathrm{HN}$ & 1.40 & 1.40 & 1.20 & - & 1.20 & 0.66 \\
\hline \multirow[t]{2}{*}{$\mathrm{PO}_{4}^{3-}$} & $\mathrm{ZM}$ & 0.06 & 0.04 & 0.06 & 0.08 & 0.10 & 0.07 \\
\hline & $\mathrm{HN}$ & 0.07 & 0.05 & 0.05 & - & 0.10 & 0.05 \\
\hline \multirow[t]{2}{*}{$\mathrm{Fe}^{2+}$} & $\mathrm{ZM}$ & 0.09 & 0.07 & 0.04 & 0.09 & 0.14 & 0.01 \\
\hline & $\mathrm{HN}$ & 0.11 & 0.08 & 0.02 & - & 0.10 & 0 \\
\hline \multirow[t]{2}{*}{$\mathrm{HS}^{-}$} & $\mathrm{ZM}$ & 0.03 & 0.03 & 0.05 & 0.07 & 0.11 & 0.08 \\
\hline & $\mathrm{HN}$ & 0.03 & 0.03 & 0.03 & - & 0.07 & 0.09 \\
\hline \multirow[t]{2}{*}{$\mathrm{SO}_{4}^{2-}$} & $\mathrm{ZM}$ & 658 & 738 & 777 & 752 & 815 & 696 \\
\hline & $\mathrm{HN}$ & 657 & 743 & 778 & - & 785 & 723 \\
\hline
\end{tabular}


Fig. 2 Variations in total $\mathrm{Fe}_{(\text {oxal })}$, its partitioning to $\mathrm{Fe}(\mathrm{II})_{\text {(oxal) }}$, $\mathrm{F}(\mathrm{IIII})_{(\text {oxal })}(\mathbf{a}, \mathbf{b})$ and total reduced sulfur, and its partitioning to acid-volatile sulfur (AVS) and chromium-reducible sulfur (CRS) compounds (c, d) in the two seagrass beds. Vertical bars indicate mean $\pm 1 \mathrm{SD}$, and bars with shared letters are not significantly different
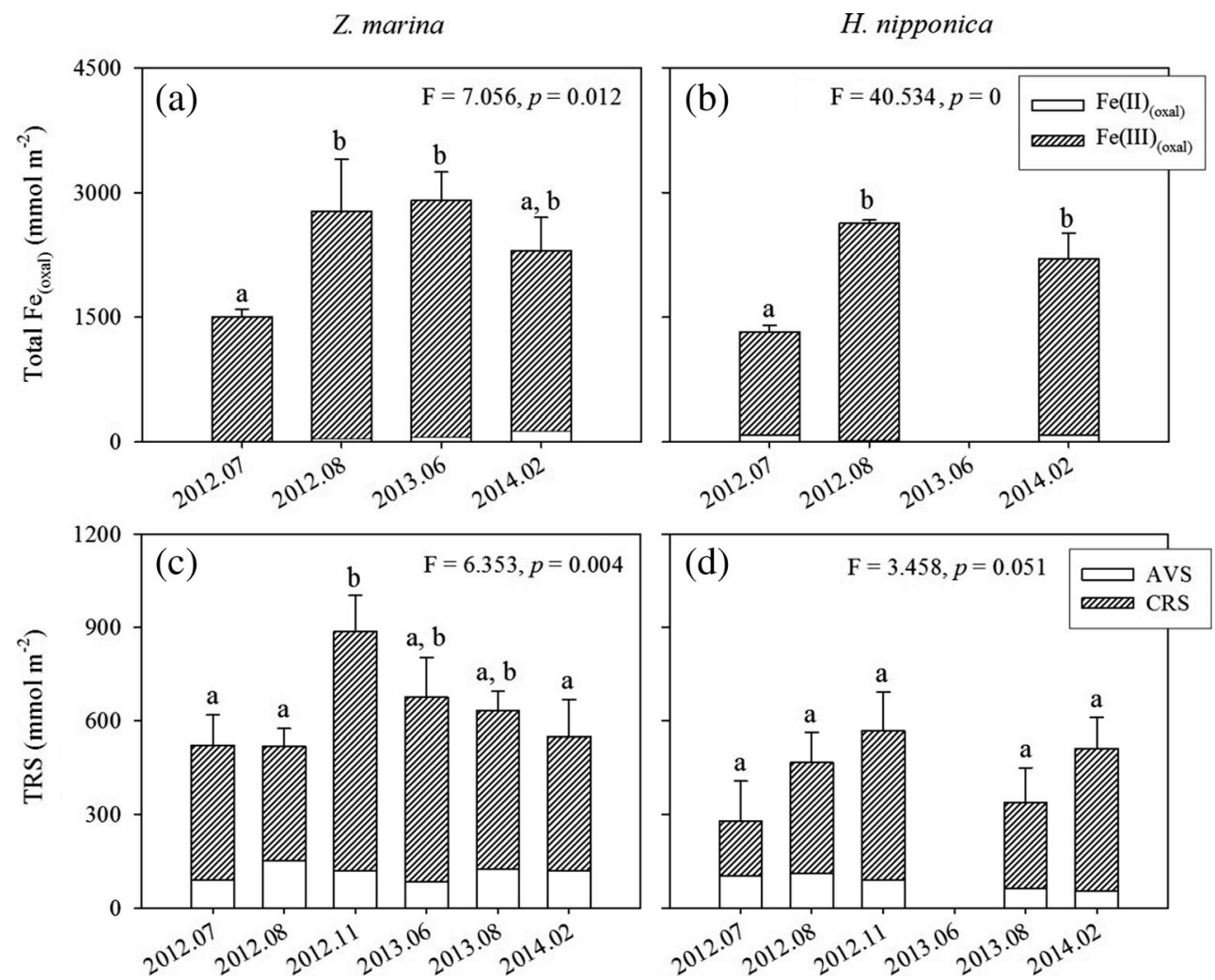

(31 mmol m $\mathrm{m}^{-2}$ day $^{-1}$ ), whereas the maximum SRR at the H. nipponica bed was observed in August 2012 $\left(15 \mathrm{mmol} \mathrm{m}^{-2} \mathrm{day}^{-1}\right)$. The lowest SRR was observed in February ( $2 \mathrm{mmol} \mathrm{m}^{-2}$ day $\left.^{-1}\right)$ at both sites. At both sites, the sulfur in AVS and CRS accounted for $49 \pm 6.5$ and $51 \pm 6.5 \%$, respectively, of the reduced sulfur produced as a result of the sulfate reduction (Fig. 3).

The turnover rates of AVS produced from sulfate reduction ranged from 0.02 to 0.37 day $^{-1}$ at the $Z$. marina bed and from 0.04 to 0.18 day $^{-1}$ at the H. nipponica bed (Fig. 4), and the turnover rate varied with season at both seagrass beds (one- way ANOVA, Z. marina bed: $F_{5,12}=37.307, p=0$; $H$. nipponica bed: $F_{4,10}=7.030, p=0.006$ ). The highest turnover rates of AVS were observed during the active growth period, i.e., in June-July at the $Z$. marina bed $\left(0.33 \pm 0.06\right.$ day $\left.^{-1}\right)$ and in July-August at the $H$. nipponica bed $\left(0.13 \pm 0.05\right.$ day $\left.^{-1}\right)$. Although the overall mean turnover rates of AVS between the $Z$. marina bed $\left(0.16 \pm 0.14\right.$ day $\left.^{-1}\right)$ and the $H$. nipponica bed $\left(0.10 \pm 0.06\right.$ day $\left.^{-1}\right)$ were not significantly different $(p=0.332)$, the highest turnover rate of AVS at the Z. marina bed was significantly higher than that at the $H$. nipponica bed during the active growth period of the two seagrass species $(p=0.014)$.

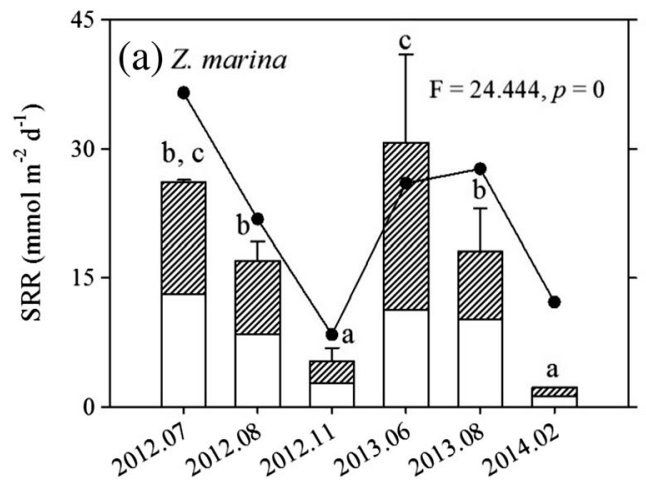

Fig. 3 Seasonal variation in sulfate reduction rates (SRRs), the partitioning of AVS and CRS in reduced sulfur produced from sulfate reduction, and below-ground biomass (BGB) in Z. marina (a) and

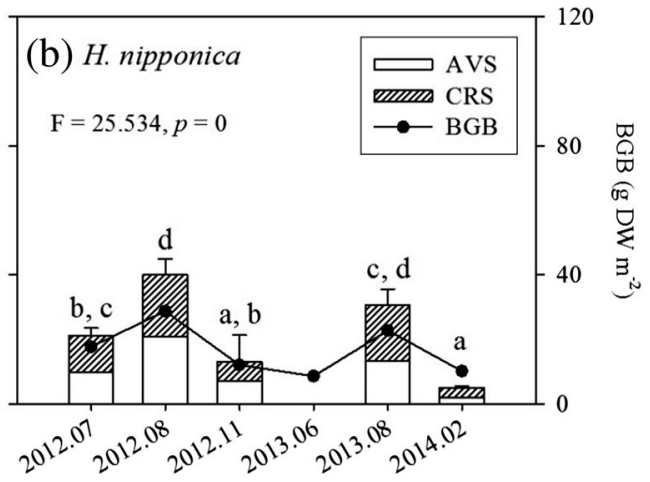

H. nipponica (b) beds. AVS and CRS denote acid-volatile sulfur and chromium-reducible sulfur, respectively. Vertical bars indicate mean \pm $1 \mathrm{SD}$ and bars with shared letters are not significantly different 

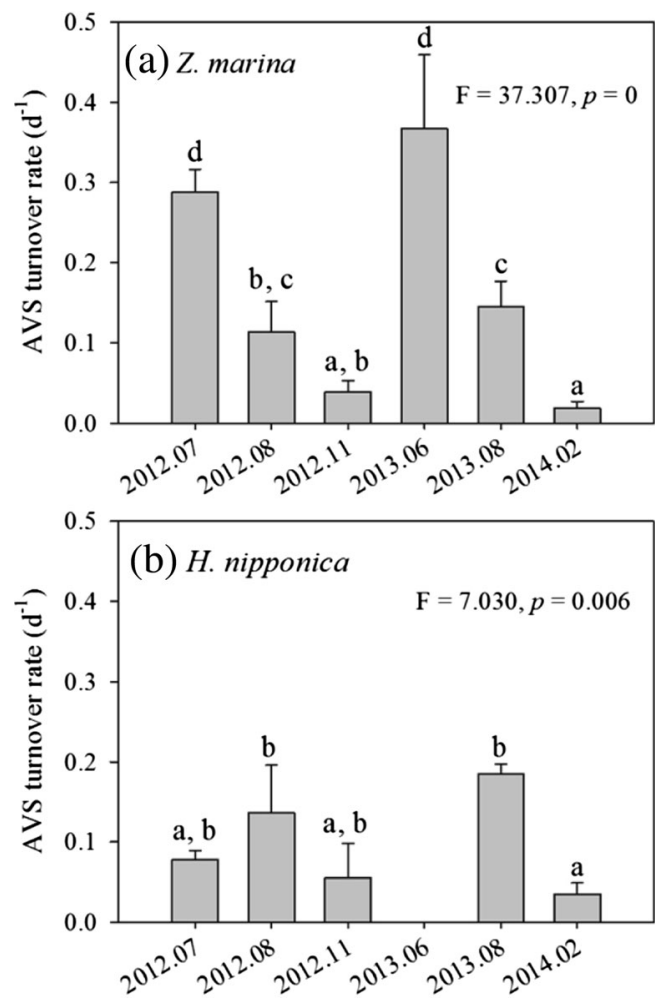

Fig. 4 Seasonal variations in AVS turnover rate in sediments of Z. marina (a) and H. nipponica (b) beds. Vertical bars indicate mean \pm $1 \mathrm{SD}$ and bars with shared letters are not significantly different

\section{Relationships Between Sulfate Reduction and Plant Biomass and Temperature}

When the SRR, AGB, BGB, and temperature data of the two seagrass beds were pooled, the correlations between SRR and BGB $(r=0.856, p=0.001)$, between SRR and AGB $(r=0.764$, $p=0.006)$, and between SRR and temperature $(r=0.713$, $p=0.014$ ) were significantly positive. In individual correlation analyses, the positive correlations between SRR and BGB were stronger at the $H$. nipponica bed $(\mathrm{y}=0.6809 \mathrm{x}-4.3162$, $\left.r^{2}=0.9878, p=0.0006\right)$ than at the $Z$. marina bed $\left(\mathrm{y}=0.3470 \mathrm{x}-4.0341, r^{2}=0.7082, p=0.0357\right)$ (Fig. 5c).
Interestingly, the correlation between SRR and temperature was significant at the $H$. nipponica bed $(\mathrm{y}=0.6146 \mathrm{x}-2.6912$, $\left.r^{2}=0.8585, p=0.0236\right)$, but not at the $Z$. marina bed $\left(y=1.2565 \mathrm{x}-6.4835, r^{2}=0.6313, p=0.0590\right)($ Fig. $5 \mathrm{a})$. The SRRs of individual species were not significantly correlated with AGB $(p>0.05)$ (Fig. 5b).

\section{Discussion}

\section{Control of Sulfate Reduction at the Two Seagrass Beds}

The SRRs at the $Z$. marina bed in the present study (2$31 \mathrm{mmol} \mathrm{m}^{-2}$ day $^{-1}$ ) were within the reported range of other temperate and tropical/subtropical seagrass beds, except at some tropical seagrass beds where dense seagrass meadows were developed (76-121 mmol m $\mathrm{m}^{-2} \mathrm{day}^{-1}$ ) (Table 3). The SRRs of H. nipponica $\left(2-15 \mathrm{mmol} \mathrm{m}^{-2}\right.$ day $\left.^{-1}\right)$ in the present study also resembled the SRRs reported at various other tropical seagrass meadows inhabited by larger species, such as Enhalus acoroides and Thalassia testudinum.

The rates and partitioning of benthic $\mathrm{C}_{\text {org }}$ oxidation are largely controlled by the availability of organic materials and electron acceptors in the sediment (Canfield et al. 2005). Due to the abundant sulfate in marine environments, the availability of organic matter is regarded as the main factor regulating sulfate reduction in seagrass beds (Holmer and Nielsen 1997; Blaabjerb et al. 1998; Devereux 2005; Marbà et al. 2006). The potential sources of organic materials in the seagrass beds include organic particles trapped in the seagrass canopy, decomposition of seagrass material, and DOM excreted from plant roots (see Marbà et al. 2006). The positive correlation between the SRR and BGB (Fig. 5c) suggested that a substantial amount of dissolved organic carbon (DOC) is released via roots and rhizomes (Moriarty et al. 1985; Blackburn et al. 1994; Blaabjerg and Finster 1998; Holmer et al. 2006). Considering the general positive relationship between the SRR and BGB, further correlation analyses for individual seagrass species revealed that the correlation between the SRR
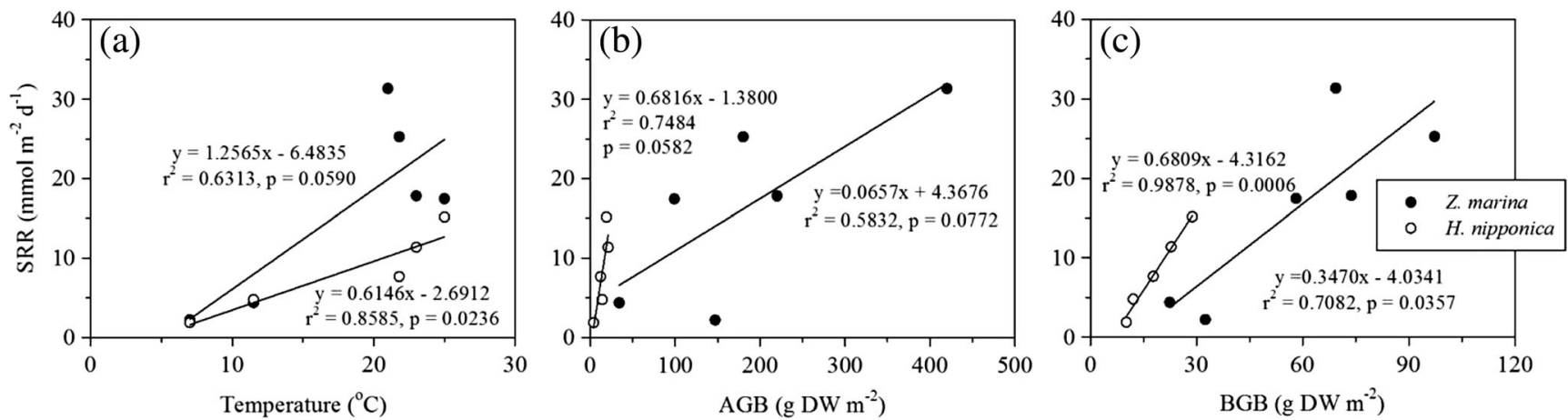

Fig. 5 Relationship between SRRs and temperature (a) and above-ground biomass (AGB, b) and BGB (c) in the sediments of $Z$. marina $(n=6)$ and $H$. nipponica $(n=5)$ beds 
Table 3 Depth-integrated sulfate reduction rates (SRRs), acid-volatile sulfur (AVS), chromium-reducible sulfur (CRS), and sediment organic matter contents (Sed OM) in various marine environments

\begin{tabular}{|c|c|c|c|c|c|c|}
\hline Seagrass species & Location & $\begin{array}{l}\text { SRRs } \\
\left(\mathrm{mmol} \mathrm{m}^{-2} \mathrm{day}^{-1}\right)\end{array}$ & $\begin{array}{l}\text { AVS } \\
\left(\mathrm{mol} \mathrm{S} \mathrm{m}^{-2}\right)\end{array}$ & $\begin{array}{l}\text { CRS } \\
\left(\mathrm{mol} \mathrm{S} \mathrm{m}^{-2}\right)\end{array}$ & $\begin{array}{l}\text { Sed OM } \\
\text { (\% dry wt.) }\end{array}$ & References \\
\hline \multicolumn{7}{|l|}{ Temperate } \\
\hline $\begin{array}{l}\text { Zostera marina } \\
\text { Halophila nipponica }\end{array}$ & Korea & $\begin{array}{l}2-31 \\
2-15\end{array}$ & $\begin{array}{l}0.08-0.15 \\
0.05-0.11\end{array}$ & $\begin{array}{l}0.43-0.78 \\
0.21-0.48\end{array}$ & $\begin{array}{l}0.84 \\
1.05\end{array}$ & This study $(0-6 \mathrm{~cm})$ \\
\hline Cymodocea nodosa & Spain & 21 & & $12.8^{\mathrm{a}}$ & & Holmer et al. (2004) $(0-10 \mathrm{~cm})$ \\
\hline Posidonia oceanica & & $3-12$ & & $0.2-3.8^{\mathrm{a}}$ & $0.38-2.56$ & Holmer et al. (2003) $(0-15 \mathrm{~cm})$ \\
\hline \multirow[t]{5}{*}{ Zostera marina } & Denmark & $25-59$ & $<0.1$ & $0.1-0.2$ & $<0.21$ & Holmer and Nielsen (1997) $(0-10 \mathrm{~cm})$ \\
\hline & Denmark & $13-30$ & - & - & $0.18-2.07$ & Boschker et al. (2000) $(0-5 \mathrm{~cm})$ \\
\hline & Netherlands & 7 & - & - & 0.73 & Boschker et al. (2000) (0-5 cm) \\
\hline & Denmark & $12-70$ & - & - & - & Blaabjerg et al. (1998) $(0-12 \mathrm{~cm})$ \\
\hline & Denmark & $19-41$ & - & $0.08-0.16^{\mathrm{a}}$ & 0.39 & Holmer and Laursen (2002) $(0-6 \mathrm{~cm})$ \\
\hline Zostera noltii & France & 29 & & & & Isaksen and Finster $(1996)(0-6 \mathrm{~cm})$ \\
\hline \multicolumn{7}{|l|}{ Tropical/subtropical } \\
\hline \multirow[t]{2}{*}{ Cymodocea rotundata } & Thailand & 6 & - & $9.7^{\mathrm{a}}$ & 0.35 & Holmer et al. (2001) $(0-16 \mathrm{~cm})$ \\
\hline & Thailand & 101 & 0.1 & 3.7 & 0.40 & Holmer et al. (2006) $(0-10 \mathrm{~cm})$ \\
\hline \multirow[t]{3}{*}{ Enhalus acoroides } & Australia & 90 & - & - & - & Pollard and Moriarty $(1991)(0-20 \mathrm{~cm})$ \\
\hline & Thailand & $6-21$ & & $9-11^{\mathrm{a}}$ & 0.53 & Holmer et al. (1999) $(0-16 \mathrm{~cm})$ \\
\hline & Thailand & 78 & 0.4 & 11.8 & 0.37 & Holmer et al. (2006) $(0-10 \mathrm{~cm})$ \\
\hline Halophila ovalis & Thailand & $76-121$ & $<0.1-0.3$ & $3.0-7.0$ & 0.15 & Holmer et al. (2006) $(0-10 \mathrm{~cm})$ \\
\hline Halodule beaudettei & Jamaica & 34 & 0.088 & 1.0 & & Blackburn et al. (1994) (0-8 cm) \\
\hline Thalassia testudinum & USA & 5 & - & & & Ku et al. (1999) $(0-8 \mathrm{~cm})$ \\
\hline
\end{tabular}

${ }^{\text {a }}$ Numbers are given as total reduced sulfur (TRS) after single-step distillation

and $\mathrm{BGB}$ of the H. nipponica bed $(\mathrm{y}=0.6809 \mathrm{x}-4.3162$, $\left.r^{2}=0.9878, p=0.0006\right)$ was stronger than that of the Z. marina bed $\left(\mathrm{y}=0.3470 \mathrm{x}-4.0341, r^{2}=0.7082\right.$, $p=0.0357$ ) (Fig. 5c). These results implied that the BGB of $H$. nipponica has a more pronounced impact on sulfate reduction than Z. marina. The relative amount of DOC exuded from below-ground tissues can be estimated from the ratio of BGB to AGB. For example, Kaldy (2012) observed that some species with a high ratio of $\mathrm{BGB}$ to AGB have higher root exudation than leaf exudation. In the present study, the BGB to AGB ratio of $H$. nipponica (1.50 on average) was three times higher than that of $Z$. marina ( 0.42 on average) (Table 1$)$.

Another interesting finding with regard to the relationship between SRR and temperature was that the H. nipponica bed showed a strong positive relationship, whereas no significant relationship between SRR and temperature was found at the Z. marina bed (Fig. 5a). This difference reflects the different growth patterns associated with the optimal growth temperature of the two species (Marsh et al. 1986). The optimal growth temperature for $Z$. marina $\left(15-20{ }^{\circ} \mathrm{C}\right)$ is relatively lower than that for H. nipponica $\left(25^{\circ} \mathrm{C}\right)$ (Kim et al. 2012). Therefore, the BGB of $Z$. marina was highest at approximately $20{ }^{\circ} \mathrm{C}$ during the spring and subsequently decreased with increasing temperature during the summer (Table 1). In contrast, the BGB of $H$. nipponica continuously increased with increasing water temperature, reaching a maximum at approximately $25^{\circ} \mathrm{C}$ during the summer (Table 1). Unlike the relationship between SRR and temperature, the SRRs exhibited maximum values at the highest BGB at both seagrass beds (Fig. 3). These results imply that sulfate reduction in seagrass sediment is not directly influenced by temperature, but is substantially affected by the amount of DOC exudation from plant roots (Holmer and Nielsen 1997; Kristensen and Alongi 2006), which co-varies with temperature. The clear differences in the optimal growth temperature for the two species further indicated that warming might deteriorate Z. marina growth and that this dominant species might eventually be replaced by $H$. nipponica in the study area (Pergent et al. 2014; Georgiou et al. 2016).

\section{Sulfur Cycles in Seagrass Sediments}

Because the SR is a prominent pathway of anaerobic $\mathrm{C}_{\mathrm{org}}$ mineralization in coastal sediments (Howarth 1984; Holmer and Nielsen 1997), understanding the S dynamics associated with SR is important, particularly in seagrass sediments because of the phytotoxic properties of sulfide to seagrass (Terrados et al. 1999; Borum et al. 2005; 
Holmer et al. 2006). Generally, the size of AVS pools $\left(\mathrm{H}_{2} \mathrm{~S}\right.$ and $\left.\mathrm{FeS}\right)$ in the TRS is controlled by variations in the SRR (Azzoni et al. 2001). The AVS in the present study accounted for a substantial fraction, comprising $49 \%$ of the S produced from SR (Fig. 3). However, despite the high AVS fraction in S resulting from SR, the AVS pools in the sediments comprised a relatively lower proportion ( $20 \%$ on average) of the TRS (Fig. 2c, d). The relatively low accumulation of AVS in the sediments, even when the SRR was high in the spring and summer, indicated that the reduced S produced from SR was rapidly recycled within the sediments of the seagrass bed, presumably via re-oxidation of $\mathrm{S}$ by $\mathrm{O}_{2}$ and/or removal of the AVS via precipitation with iron compounds, including dissolved iron and $\mathrm{Fe}$ oxides. With regard to reoxidation of reduced sulfur by oxygen, seagrass transfers photosynthetically produced oxygen to root tissues using their internal air space, thereby providing oxygen to the surrounding sediment (Azzoni et al. 2001). The exported oxygen conducts both biotic and abiotic re-oxidation of sulfide in the rhizosphere (Canfield et al. 2005). Indeed, the turnover rate of AVS produced by sulfate reduction (Fig. 4) varied with fluctuations in BGB (Table 1). These results indicated that sulfide re-oxidation is highly associated with the supply of oxygen released from the root during the optimal growth period of seagrass (Holmer et al. 2006). On the other hand, iron oxyhydroxides (i.e., $\mathrm{FeOOH}$ ) in the sediments first react with sulfides to produce dissolved $\mathrm{Fe}^{2+}$, which subsequently react with sulfide to produce iron monosulfide (FeS) (Azzoni et al. 2001; Canfield et al. 2005). Finally, thermodynamically unstable $\mathrm{FeS}$ is transformed into more stable pyrite $\left(\mathrm{FeS}_{2}\right)$ and precipitated in the sediments (Jørgensen 1977). Therefore, the presence of iron compounds in the sediments diminishes the accumulation of AVS in the sediments via precipitation of iron sulfide $\left(\mathrm{FeS}_{2}\right)$. In the present study, $\mathrm{Fe}(\mathrm{III})_{(\text {oxal })}$ was abundant (20-48 $\mu \mathrm{mol} \mathrm{cm} \mathrm{cm}^{-3}$, with concentrations higher than those reported in other sandy sediments in Denmark (0$8 \mu \mathrm{mol} \mathrm{cm} \mathrm{cm}^{-3}$, Kristensen et al. 2002, 2003), and accounted for most of the solid phase iron, comprising 94-100\% of the total $\mathrm{Fe}_{\text {(oxal) }}$. Therefore, the low concentrations of sulfide and dissolved iron observed at both seagrass beds implied a rapid reaction between sulfide and iron compounds $\left(\mathrm{Fe}^{2+}\right.$ and $\left.\mathrm{FeOOH}\right)$ (Canfield 1989). Consequently, pyrite is regarded as a major reduced $\mathrm{S}$ compound in most seagrass sediments (Holmer et al. 2006). Similarly, these results showed a significant relationship between the total $\mathrm{Fe}_{\text {(oxal) }}$ and CRS concentrations $\left(r^{2}=0.3344, p=0.0076\right)$ (Fig. 6), indicating that most reduced $\mathrm{S}$ compounds were bound to $\mathrm{Fe}$ to form pyrite (Devereux et al. 2011). Therefore, owing to the relevant biogeochemical interaction between sulfur, iron, and oxygen in the rhizosphere, the seagrasses in the study area were hardly exposed to the phytotoxic effects of sulfide.

\section{Biogeochemical Implications of the Expansion of $\boldsymbol{H}$. nipponica in Coastal Waters}

Temperature is a critical factor regulating the growth and survival of seagrass, and thus, global warming could ultimately induce a distributional range shift, resulting in a decline of temperate seagrass species and the expansion of subtropical/ tropical seagrass species (Moore and Jarvis 2008; ISAC 2011; Georgiou et al. 2016). For example, the shoot density of Z. marina decreased by $48 \%$ at elevated temperatures to $4{ }^{\circ} \mathrm{C}$ above ambient temperature (Touchette et al. 2003). Although it is generally hypothesized that $15^{\circ} \mathrm{C}$ is the lower temperate limit for some Halophila spp. (Hillman et al. 1995; Bianchi 2007), H. nipponica remained alive by maintaining a high ratio of BGB to AGB when the water temperature was below $15{ }^{\circ} \mathrm{C}$ along the southern coast of Korea (Kim et al. 2012). Similarly, Georgiou et al. (2016) demonstrated that Halophila stipulacea, an invasive species in the Mediterranean Sea, ceases clonal growth during winter (at $10{ }^{\circ} \mathrm{C}$ ) but continues to undergo photosynthesis and produces leaf biomass. The average water temperature in the winter (February) increased by approximately $2{ }^{\circ} \mathrm{C}$ (from 8.4 to $10.1^{\circ} \mathrm{C}$ ) during the past 70 years in southern coastal waters of the Korean peninsula (Kim et al. 2009). In this context, our findings of a higher BGB to AGB ratio in winter (2.55 in February, Table 1) and a significant correlation between the SRR and BGB and SRR and temperature in the H. nipponica bed sediment (Fig. 5a, c) confirm a distributional range shift of H. nipponica (Kim et al. 2009; Kim et al. 2012). Thus, it is reasonable to speculate that increased SST might lead to the spread of $H$. nipponica meadows in Korean coastal waters.

The expansion of $H$. nipponica in coastal waters might have significant biogeochemical implications on $\mathrm{S}$ cycles in sediments. In the present study, the relationship between SRR

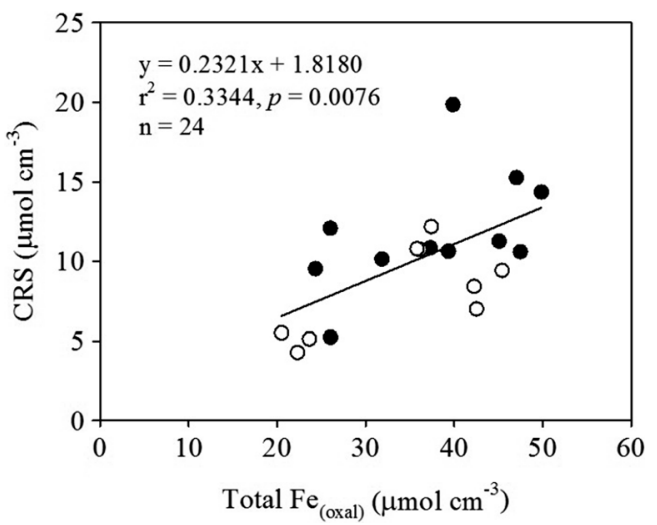

Fig. 6 Comparison of total $\mathrm{Fe}_{(\text {oxal })}$ and chromium-reducible sulfur (CRS) concentrations in the sediments of $Z$. marina and $H$. nipponica beds. The values are the mean concentrations for triplicate cores $(n=24)$ 
and BGB was more significant at the $H$. nipponica bed than at the $Z$. marina bed (Fig. 5c). In addition, the highest turnover rate of AVS during the active growth period in the $H$. nipponica bed $\left(0.13 \pm 0.05\right.$ day $\left.^{-1}\right)$ was 2.5 times lower than that of the $Z$. marina bed $\left(0.33 \pm 0.06\right.$ day $\left.^{-1}\right)$ (Fig. 4). A stronger relationship between SRR and BGB but lower turnover rates (i.e., longer residence time) of AVS in the $H$. nipponica bed suggests high possibility of sulfide accumulation at the $H$. nipponica bed at elevated temperatures in the future. Consequently, continuous warming is likely to replace cold affinity $Z$. marina with warm affinity $H$. nipponica, which might provoke relatively rapid sulfide accumulation in the seagrass meadow. The warming of seawater will ultimately intensify the stratification of the surface water column and might induce hypoxic conditions in bottom waters (Coma et al. 2009; Middelburg and Levin 2009). Hypoxic conditions further restrict the supply of Fe oxides and thus sequentially enhance the accumulation of sulfide in sediment (Kristensen et al. 2003; Hyun et al. 2013). Several Mediterranean seagrass meadows have suffered from sulfide stress triggered by increased water temperature (Marbà and Duarte 2010; Gracía et al. 2012, 2013). Therefore, it is particularly important to monitor and investigate the biogeochemical impacts of the extension of warm affinity $H$. nipponica resulting from seawater warming in Korean coastal waters.

\begin{abstract}
Acknowledgements This research was a part of the project entitled "Long-term change of structure and function in marine ecosystems of Korea" funded by the Korean Ministry of Oceans and Fisheries. We thank two reviewers for their valuable comments that improved the earlier version of the manuscript.
\end{abstract}

Open Access This article is distributed under the terms of the Creative Commons Attribution 4.0 International License (http:// creativecommons.org/licenses/by/4.0/), which permits unrestricted use, distribution, and reproduction in any medium, provided you give appropriate credit to the original author(s) and the source, provide a link to the Creative Commons license, and indicate if changes were made.

\section{References}

Azzoni, R., G. Giordani, M. Bartoli, D.T. Welsh, and P. Viaroli. 2001. Iron, sulphur and phosphorus cycling in the rhizosphere sediments of a eutrophic Ruppia cirrhosa meadow (Valle Smarlacca, Italy). Journal of Sea Research 45: 15-26.

Bianchi, C.N. 2007. Biodiversity issues for the forthcoming tropical Mediterranean Sea. Hydrobiologia 580: 7-21.

Blaabjerg, V., K.N. Mouritsen, and K. Finster. 1998. Diel cycles of sulphate reduction rates in sediments of a Zostera marina bed (Denmark). Aquatic Microbial Ecology 15: 97-102.

Blaabjerg, V., and K. Finster. 1998. Sulfate reduction associated with roots and rhizomes of the marine macrophyte Zostera marina. Aquatic Microbial Ecology 15: 311-314.

Blackburn, T.H., D.B. Nedwell, and W.J. Wiebe. 1994. Active mineral cycling in a Jamaican seagrass sediment. Marine Ecology Progress Series 110: 233-239.
Boschker, H.T.S., A. Wielemaker, B.E.M. Schaub, and M. Holmer. 2000. Limited coupling of macrophyte production and bacterial carbon cycling in the sediments of Zostera spp. meadows. Marine Ecology Progress Series 203: 181-189.

Borum, J., O. Pedersen, T.M. Greve, T.A. Frankovich, J.C. Zieman, J.W. Fourqurean, and C.J. Madden. 2005. The potential role of plant oxygen and sulphide dynamics in die-off events of the tropical seagrass, Thalassia testudunum. Journal of Ecology 93: 148-158.

Canfield, D.E. 1989. Reactive iron in marine sediments. Geochimica et Cosmochimica Acta 53: 619-632.

Canfield, D.E., E. Kristensen, and B. Thamdrup. 2005. Aquatic geomicrobiology. Elsevier Academic Press.

Canfield, D.E., B. Thamdrup, and J.W. Hansen. 1993. The anaerobic degradation of organic matter in Danish coastal sediments: iron reduction, manganese reduction, and sulfate reduction. Geochimica et Cosmochimica Acta 57: 3867-3883.

Cline, J.D. 1969. Spectrophotometric determinations of hydrogen sulfide in natural waters. Limnology and Oceanography 14: 454-458.

Coma, R., M. Ribes, E.S. Errano, E. Jiménez, J. Salat, and J. Pascual. 2009. Global warming-enhanced stratification and mass mortality events in the Mediterranean. Proceedings of National Academy of Sciences of the United States of America 106: 6176-6181.

Connolly, R.M. 2012. Seagrass. In A marine climate change impacts and adaptation report card for Australia. ed. E.S. Poloczanska, A.J. Hobday, and A.J. Richardson, http://www.oceanclimate-change. org.au, pp. 177-185.

den Hartog, C., and J. Kuo. 2006. Taxonomy and biogeography of seagrasses. In Seagrasses: biology, ecology and conservation, ed. A.W.D. Larkum, R.J. Orth, and C.M. Duarte, 1-23. Dordrecht: Springer.

Devereux, R. 2005. Seagrass rhizosphere microbial communities. In Interactions between macro- and microorganisms in marine sediment, ed. E.K. Kristensen, R.R. Haese, and J.E. Kostka, 199216. DC, American Geophysical Union: Washington.

Devereux, R., D.F. Yates, J. Aukamp, R.L. Quarles, S.J. Jordan, R.S. Stanley, and P.M. Eldridge. 2011. Interactions of Thalassia testudinum and sediment biogeochemistry in Santa Rosa sound, NW Florida. Marine Biology Research 7: 317-331.

Diaz-Almela, E., N. Marbà, and C.M. Duarte. 2007. Consequences of Mediterranean warming events in seagrass (Posidonia oceanica) flowering records. Global Change Biology 13: 224-235.

Folk, R.L., and W.C. Ward. 1957. Brazos river bar: a study in the significance of grain size parameters. Journal of Sedimentary Petology 27: 3-26.

Fossing, H., and B.B. Jørgensen. 1989. Measurement of bacterial sulfate reduction in sediment: evaluation of a single-step chromium reduction method. Biogeochemistry 8: 205-222.

Fourqurean, J.W., C.M. Duarte, H. Kennedy, N. Marbà, M. Holmer, M.A. Mateo, E.T. Apostolaki, G.A. Kendrick, D. Krause-Jensen, K.J. McGlathery, and O. Serrano. 2012. Seagrass ecosystems as a globally significant carbon stock. Nature Geoscience 5: 505-509.

Georgiou, D., A. Alwxandre, J. Luis, and R. Santos. 2016. Temperature is not a limiting factor for the expansion of Halophila stipulacea throughout the Mediterranean Sea. Marine Ecology Progress Series 544: 159-167.

Gracía, R., M. Sánchez-Camacho, C.M. Duarte, and N. Marbà. 2012. Warming enhances sulphide stress of Mediterranean seagrass (Posidonia oceanica). Estuarine, Coastal and Shelf Science 113: 240-247.

García, R., M. Holmer, C.M. Duarte, and N. Marbà. 2013. Global warming enhances sulphide stress in a key seagrass species (NW Mediterranean). Global Change Biology 19: 3629-3639.

Grasshoff, K., M. Ehrhardt, and K. Krernling. 1999. Methods of seawater analysis. third ed, 208-226. Weinbeim: Wiley-VCH.

Hall, P.O., and R.C. Aller. 1992. Rapid small-volume, flow injection analysis for $\mathrm{CO}_{2}$ and $\mathrm{NH}_{4}^{+}$in marine sediment and freshwaters. Limnology and Oceanography 37: 113-119. 
Hemminga, M.A., and C.M. Duarte. 2000. Seagrass ecology. Cambridge: Cambridge University Press.

Hillman, K., A.J. McComb, and D.I. Walker. 1995. The distribution, biomass and primary production of the seagrass Halophila ovalis in the Swan/ Canning Estuary, Western Austrailia. Aquatic Botany 51: 1-54.

Holmer, M., F.Ø. Andersen, N. Holmboe, E. Kristensen, and N. Thongtham. 1999. Transformation and exchange processes in the Bangrong mangrove forest-seagrass bed system, Thailand. Seasonal and spatial variations in benthic metabolism and sulfur biogeochemistry. Aquatic Microbial Ecology 20: 203-212.

Holmer, M., F.Ø. Andersen, S.L. Nielsen, and H.T.S. Boschker. 2001. The importance of mineralization based on sulfate reduction for nutrient regeneration in tropical seagrass sediments. Aquatic Botany 71: 1-17.

Holmer, M., C.M. Duarte, H.T.S. Boschker, and C. Barrón. 2004. Carbon cycling and bacterial carbon sources in pristine and impacted Mediterranean seagrass sediments. Aquatic Microbial Ecology 36: 227-237.

Holmer, M., C.M. Duarte, and N. Marbà. 2003. Sulfur cycling and seagrass (Posidonia oceanica) status in carbonate sediments. Biogeochemistry 66: 223-239.

Holmer, M., and L. Laursen. 2002. Effect of shading of Zostera marina (eelgrass) on sulfur cycling in sediments with contrasting organic matter and sulfide pools. Journal of Experimental Marine Biology and Ecology 270: 25-37.

Holmer, M., N. Marbà, M. Lamote, and C.M. Duarte. 2009. Deterioration of sediment quality in seagrass meadows (Posidonia oceanica) invaded by macroalgae (Caulerpa sp.). Estuaries and Coasts 32: 456-466.

Holmer, M., and S.L. Nielsen. 1997. Sediment sulfur dynamics related to biomass-density patterns in Zostera marina (eelgrass) beds. Marine Ecology Progress Series 146: 163-171.

Holmer, M., O. Pedersen, and K. Ikejima. 2006. Sulfur cycling and sulfide intrusion in mixed Southeast Asian tropical seagrass meadows. Botanica Marina 49: 91-102.

Howarth, R.W. 1984. The ecological significance of sulfur in the energy dynamics of salt marsh and coastal marine sediments. Biogeochemistry 1: 5-27.

Hyun, J.-H., A.C. Smith, and J.E. Kostka. 2007. Relative contributions of sulfate- and iron(III) reduction to organic matter mineralization and process controls in contrasting habitats of the Georgia saltmarsh. Applied Geochemistry 22: 2637-2651.

Hyun, J.-H., J.-S. Mok, H.-Y. Cho, S.-H. Kim, K.S. Lee, and J.E. Kostka. 2009. Rapid organic matter mineralization coupled to iron cycling in intertidal mud flats of the Han River estuary, Yellow Sea. Biogeochemistry 92: 231-245.

Hyun, J.-H., S.-H. Kim, J.-S. Mok, J.S. Lee, S.-U. An, W.-C. Lee, and R.H. Jung. 2013. Impacts of long-line aquaculture of Pacific oysters (Crassostrea gigas) on sulfate reduction and diffusive nutrient flux in the coastal sediments of Jinhae-Tongyeong, Korea. Marine Pollution Bulletin 74: 187-198.

IPCC. 2007. Climate change 2007: the physical science basis. In Contribution of Working Group I to the Fourth Assessment Report of the Intergovernmental Panel on Climate Change, ed. S.E.Q. Solomon, M. Manning, Z. Chen, M. Marquis, K.B. Averyt, M. Tignor, and H.L. Miller. Cambridge, United Kingdom and New York, NY, USA: Cambridge University Press.

ISAC 2011. Marine bioinvasions and climate change. Approved by ISAC on 16 June 2011 for the National Invasive Species Council Available.

Isaksen, M.F., and K. Finster. 1996. Sulphate reduction in the root zone of the seagrass Zostera noltii on the intertidal flats of a coastal lagoon (Arcachon, France). Marine Ecology Progress Series 137: 187-194.

Jørgensen, B.B. 1977. The sulfur cycle of a coastal marine sediment (Limfjorden, Denmark). Limnology and Oceanography 22: 814-832.

Jørgensen, B.B. 1978. A comparison of methods for the quantification of bacterial sulfate reduction in coastal marine sediments, 1 .
Measurement with radiotracer techniques. Geomicrobiology Journal 1: 11-28.

Kaldy, J. 2012. Influence of light, temperature and salinity on dissolved organic carbon exudation rates in Zostera marina L. Aquatic Biosystems 8: 19.

Kim, J.B., J.-I. Park, C.-S. Jung, P.-Y. Lee, and K.-S. Lee. 2009. Distributional range extension of the seagrass Halophila nipponica into coastal waters off the Korean peninsula. Aquatic Botany 90: 269-272.

Kim, S.H., Y.K. Kim, S.R. Park, and K.-S. Lee. 2012. Growth dynamics of the seagrass Halophila nipponica, recently discovered in temperate coastal waters of the Korean peninsula. Marine Biology 159: 255-267.

Koch, M.S., S. Schopmeyer, C. Kyhn-Hansen, and C.J. Madden. 2007. Synergistic effects of high temperature and sulfide on tropical seagrass. Journal of Experimental Marine Biology and Ecology 341: 91-101.

Kristensen, E., and D.M. Alongi. 2006. Control by fiddler crabs (Uca vocans) and plant roots (Avicennia marina) on carbon, iron, and sulfur biogeochemistry in mangrove sediment. Limnology and Oceanography 51: 1557-1571.

Kristensen, E., K.D. Kristiansen, and M.H. Jensen. 2003. Temporal behavior of manganese and iron in a sandy coastal sediment exposed to water column anoxia. Estuaries 26: 690-699.

Kriestiansen, K.D., E. Krestensen, and M.H. Jensen. 2002. The influence of water column hypoxia on the behavior of manganese and iron in sandy coastal marine sediment. Estuarine, Coastal and Shlef Science 55: 645-654.

Ku, T.C.W., L.M. Walter, M.L. Coleman, R.E. Blake, and A.M. Martini. 1999. Coupling between sulfur recycling and syndepositional carbonate dissolution: evidence from oxygen and sulfur isotope composition of pore water sulfate, South Florida Platform, U.S.A. Geochimica et Cosmochimica Acta 63: 2529-2546.

Kuo, J., Z. Kanamoto, H. Iizumi, K. AioK, and H. Mukai. 2006a. Seagrassess from the Nansei Islands, Southern Japanese Archipelago: species composition, distribution and biogeography. Marine Ecology 27: 290-298.

Kuo, J., Z. Kanamoto, H. Iizumi, K. Aio, and H. Mukai. 2006b. Seagrasses of the genus Halophila Thouars (Hydrocharitaceae) from Japan. Acta Phytotaxonomica Geobotanica 57 (2): 129-154.

Lavery, P.S., M.-A. Mateo, O. Serrano, and M. Rozaimi. 2013. Variability in the carbon storage of seagrass habitats and its implications for global estimates of blue carbon ecosystem service. PloS One 8.

Lee, K.-S., and S.Y. Lee. 2003. The seagrasses of the republic of Korea. In World atlas of seagrasses: present status and future conservation, ed. E.P. Green and F.T. Short, 193-198. California: University of California Press.

Lee, K.-S., S.R. Park, and J.-B. Kim. 2005. Production dynamics of the eelgrass, Zostera marina in two bay systems on the south coast of the Korean peninsula. Marine Biology 147: 1091-1108.

Lovley, D.R., and E.J.P. Phillips. 1987. Competitive mechanisms for inhibition of sulfate reduction and methane production in the zone of ferric iron reduction in sediments. Applied and Environmental Microbiology 53: 2636-2641.

Marbà, N., and C.M. Duarte. 2010. Mediterranean warming triggers seagrass (Posidonia oceanica) shoot mortality. Global Change Biology 16: 2366-2375.

Marbà, N., M. Holmer, and E. Gacia. 2006. Seagrass beds and coastal biogeochemistry. In Seagrasses: biology, ecology and conservation, ed. A.W.D. Larkum, R.J. Orth, and C.M. Duarte. Netherlands: Springer.

Marsh, J.A. Jr., W.C. Dennison, and R.S. Alberte. 1986. Effects of temperature on photosynthesis and respiration in eelgrass (Zostera marina L.). Journal of Experimental Marine Biology and Ecology 101: 257-267.

Middelburg, J.J., and L.A. Levin. 2009. Coastal hypoxia and sediment biogeochemistry. Biogeosciences 6: 1273-1293. 
Moore, K.A., and J.C. Jarvis. 2008. Environmental factors affecting recent summertime eelgrass diebacks in the lower Cheaspeake Bay: implications for long-term persistence. Journal of Coastal Research 55: 135-147.

Moriarty, D.J.W., P.I. Boon, J.A. Hansen, W.G. Hunt, I.R. Poiner, P.C. Pollard, G.W. Skyring, and D.C. White. 1985. Microbial biomass and productivity in seagrass beds. Geomicrobiology Journal 4 (1): 21-51.

Nellemann, C., E. Corcoran, C.M. Duarte, L. Valdes, C. De Young, L. Fonseca, and G. Grimsditch. 2009. Blue carbon: a rapid response assessment. GRID-Arendal: United Nations Environment Programmes.

Orth, R.J., T.J.B. Carruthers, W.C. Dennison, C.M. Duarte, J.W. Fourqurean, K.L. Heck Jr., A.R. Hughes, G.A. Kendrick, W.J. Kenworthy, S. Olyarnik, F.T. Short, M. Waycott, and S.L. Williams. 2006. A global crisis for seagrass ecosystems. Bioscience 56: 987-996.

Parsons, T.R., Y. Maita, and C.M. Lalli. 1984. A manual of chemical and biological methods for seawater analysis. Pergamon press.

Pergent, G., N. Bazairi, C.N. Bianchi, C.-F. Boudouresque, M.-C. Buia, S. Calvo, P. Clabaut, M. Harmelin-Vivien, M.A. Mateo, M. Montefalcone, C. Morri, S. Orfanidis, C. Pergent-Martini, R. Semroud, O. Serrano, T. Thibaut, A. Tomasello, and M. Verlaque. 2014. Climate change and Mediterranean seagrass meadows: a synopsis for environmental managers. Mediterranean Marine Science 15: 462-473.

Phillips, W.J.P., and D.R. Lovley. 1987. Determination of Fe(III) and $\mathrm{Fe}(\mathrm{II})$ in oxalate extracts of sediment. Soil Science Society of America Journal 51: 938-941.

Pollard, P.C., and D.J.W. Moriarty. 1991. Organic carbon decomposition, primary and bacterial productivity, and sulphate reduction, in tropical seagrass beds of the Gulf of Carpentaria, Australia. Marine Ecology Progress Series 69: 149-159.
Rasheed, M.A., and R.K.F. Unsworth. 2011. Long-term climate-associated dynamics of a tropical seagrass meadow: implications for the future. Marine Ecology Progress Series 422: 93-103.

Short, F. 1987. Effects of sediment nutrients on seagrasses: literature review and mesocosm experiment. Aquatic Botany 27: 41-57.

Short, F., E. Fernandez, A. Vernon, and J.L. Gaeckle. 2006. Occurrence of Halophila baillonii meadows in Belize, Central America. Aquatic Botany 85: 249-251.

Short, F., T. Carruthers, W. Dennison, and M. Waycott. 2007. Global seagrass distribution and diversity: a bioregional model. Journal of Experimental Marine Biology and Ecology 350: 3-20.

Stookey, L.L. 1970. Ferrozine-a new spectrophotometric reagent for iron. Analytical Chemistry 42: 779-781.

Terrados, J., D.M. Duarte, L. Kamp-Nielsen, N.S.R. Agawin, E. Gacia, D. Lacap, M.D. Fortes, J. Borum, M. Lubanski, and T. Greve. 1999. Are seagrass growth and survival constrained by the reducing conditions of the sediment? Aquatic Botany 65: 175-197.

Thamdrup, B., and E.D. Canfield. 1996. Pathways of carbon oxidation in continental margin sediments of central Chile. Limnology and Oceanography 41: 1629-1650.

Touchette, B.W., J.M. Burkholder, and H.B. Glasgow. 2003. Variations in eelgrass (Zostera marina L.) morphology and internal nutrient composition as influenced by increased temperature and water column nitrate. Estuaries 26: 142-155.

Waycott, M., C.M. Duarte, T.J.B. Carruthers, R.J. Orth, W.C. Dennison, S. Olyarnik, A. Calladine, J.W. Fourqurean, K.L. Heck, A.R. Hughes, G.A. Kendrick, W.J. Kenworthy, F.T. Short, and S.L. Williams. 2009. Accelerating loss of seagrasses across the globe threatens coastal ecosystems. Proceedings of National Academy of Sciences of the United States of America 106: 12377-12381.

Zimmerman, R.C., V.J. Hill, and C.L. Gallegos. 2015. Predicting effects of ocean warming, acidification, and water quality on Chesapeake region eelgrass. Limnology and Oceanography 60: 1781-1804. 